\title{
Depuration Capacity of Mussels (Mytilus galloprovincialis) in Presence of Marteilia Spp. Parasites
}

Article · January 2016

DOI: $10.4172 / 2155-9910.1000187$

CITATIONS

0

5 authors, including:
READS

50

\section{Cristina Canonico}

Istituto Zooprofilattico Sperimentale Umbria ...

16 PUBLICATIONS 198 CITATIONS

SEE PROFILE

Alberto Felici

University of Camerino

13 PUBLICATIONS 31 CITATIONS

SEE PROFILE
Stefano Rea

University of Camerino

30 PUBLICATIONS 161 CITATIONS

SEE PROFILE

\section{Gabriele Angelico}

Istituto Zooprofilattico Sperimentale Umbria... 5 PUBLICATIONS 1 CITATION

SEE PROFILE 


\title{
Depuration Capacity of Mussels (Mytilus galloprovincialis) in Presence of Marteilia Spp. Parasites
}

Cristina Canonico ${ }^{1}$, Francesca Barchiesi ${ }^{1}$, Stefano Rea ${ }^{2}$, Alberto Felici ${ }^{2}$, Annarita Loschi ${ }^{2}$, Roberta Stocchi ${ }^{2}$, Gabriele Angelico ${ }^{1}$ and Mario Latini $^{1 *}$

${ }^{1}$ Institute Zooprofilattico Umbria and the Marches, Perugia, Italy

${ }^{2}$ University of Camerino, Faculty of Veterinary Medicine, Matelica (Macerata), Italy

\begin{abstract}
Bivalve molluscs are filter-feeding organisms present in the water column: during their activity, they could retain micro-organisms that are potentially dangerous to human health. For this reason, EU Regulations may require that a purification treatment be performed prior to bivalve trade. The length of the purification process could be affected by stress factors, such as parasitic infections. The purpose of this study was to determine if the presence of Marteilia spp. parasite in shellfish could modify time and efficacy of their microbiological purification treatment, in order to set up specific protocols. Lysosomal membrane stability, phagocytosis capacity, granulocyte/hyalinocyte rate and neutral lipid accumulation are biomarkers used to evaluate shellfish physiological state. These biomarkers were used to exclude any differences caused by stressor factors that could affect the purification results. Mussels were sampled from two different production areas. The presence or absence of parasites was confirmed by cytological test. Both groups of parasitized and non-parasitized mussels were contaminated with E.coli: they were then sampled for microbiological analyses and tested for biomarkers for up to 70 hours of purification. Parasitized and non-parasitized molluscs did not show any differences in levels of $E$. coli after 12, 24, 36, 48 and 70 hours of depuration. In relation to biomarkers, mussels seem to react to Lysosomal membrane stability in presence of Marteilia. The present study shows that the presence of Marteilia spp. does not affect the purification rate of mussels.
\end{abstract}

\section{Keywords: Mussels; Depuration; E. coli; Marteilia; Parasite}

\section{Introduction}

Bivalve molluscs are sedentary filter feeder animals, feeding on small food particles present in water columns or sediments. Molluscs are able to filter different amounts of water depending on several factors. Mytilus galloprovincialis filtration rate is up to 2.5 liters of water per hour [1], while for M. edulis the individual filtration rate is up to 5 liters of water per hour [2]. During this intense filtering activity, bivalve molluscs retain plankton necessary for their metabolism, as well as bacteria, viruses and parasites that may be present in the environment. Some of these contaminants can be dangerous to human health, especially when shellfish are eaten raw or under-cooked [3]. In order to limit such a risk in the human food chain, EU Regulations may require that a purification treatment be performed prior to the trade of bivalve molluscs. Such a process consists in a short relaying period of the bivalve molluscs in tanks, where they can filter clean sea water. Some factors, like processing time of the product, physical and chemical characteristics of the water and the shellfish filtering capacity, may be critical to the process effectiveness [4]. Furthermore, stress and health state of bivalve molluscs have been largely discussed by several authors as main factors capable of interfering with filtering capacity and purification process [5]. The purification rate of bivalve molluscs could be affected by the presence of parasites of the Marteilia species, a common parasite of Mytilus galloprovincialis [6]. The reason is that Marteilia can create a mechanical blockage of digestive tubules in the bivalve molluscs host, and consequently feeding capacities could be reduced [7]. This can influence the time required for freeing bivalve molluscs from agents that are potentially dangerous for consumers. Being Mytilus galloprovincialis the dominant species found along the Italian coast, it is important to know whether parasites can affect the safety process of bivalve molluscs food chain.

In order to evaluate shellfish physiological state, ecotoxicology provides useful tests as „time- integrated” tools, able to monitor their state for a longer period. A number of biomarkers covering a range of toxic endpoints have been used as specific or aspecific markers of interactive or cumulative toxic effects $[8,9]$. Such biological effect markers are cheap to test, easily reproducible and do not require any specific equipment. Each biomarker can give specific indications; however, data provided by single biomarker show more detailed and useful information when compared with each other. Therefore, it is preferable to work with a battery of biomarkers. Some studies showed that parasitic infections can be considered as indicators of environmental quality $[10,11]$, since they are capable of causing changes in the conditions indexes of mussels, although such indicators are not necessarily related to their welfare. In fact, mussels that were found parasite-free over the entire year did not show higher welfare indexes than parasitized ones [12]. Parasites belonging to Marteilia species have an indirect transmission between shellfish. Direct transmission of Marteilia parasites between bivalve molluscs through experiment of co-habitation and by injection was unsuccessful. The same happened through feeding with spore suspension [13].

The purpose of this study was to determine whether a purification plant should take into account the presence of shellfish parasites spread in the environment and the possible consequent stress in mussels, in

*Corresponding author: Mario Latini, Institute Zooprofilattico Umbria and the Marches, Perugia, Italy, Tel: +39 07141760; Fax: +3907142758; E-mail: m.latini@izsum.it

Received February 22, 2016; Accepted March 17, 2016; Published March 21 2016

Citation: Canonico C, Barchiesi F, Rea S, Felici A, Loschi A, et al. (2016) Depuration Capacity of Mussels (Mytilus galloprovincialis) in Presence of Marteilia Spp. Parasites. J Marine Sci Res Dev 6: 187. doi:10.4172/2155-9910.1000187

Copyright: () 2016 Canonico C, et al. This is an open-access article distributed under the terms of the Creative Commons Attribution License, which permits unrestricted use, distribution, and reproduction in any medium, provided the original author and source are credited. 
order to set up specific protocols for their microbiological purification. During the experiment, the two groups' purification rate was compared to assess if the presence of parasites could influence its value. Some stress biomarkers were selected and assessed in Marteilia spp. parasitized mussels (M. galloprovincialis), as well as in Marteilia-free subjects, to investigate their stress status at the beginning and during the purification treatment. Biomarkers were chosen as good indexes for environmental stress [14-17]. Throughout the experiment, the entire process and environment were monitored to ensure that no external factors could affect the performance of the purification process.

The purification rate was calculated on contamination with E. coli, since its presence in flesh and intravalvular liquid (FIL) represents the legislative parameter used to decide on the commercial destination of bivalve molluscs, including the need of purification, as required by Regulations CE 853/2004, CE 854/2004 and CE 2073/2005.

\section{Materials and Methods}

Seven kilograms of commercial size mussels (M. galloprovincialis) with a shell length over $5 \mathrm{~cm}$ were sampled from two different production areas. Presence of parasites (Marteilia spp.) for one of the examined areas was confirmed through cytological test, while the other zone was verified as parasite-free. The experiment was repeated in May, June and October, in order to investigate mussels' general conditions, as well as the possible occurrence of a seasonal trend for the parasite presence. For each repetition, samples were transported to the laboratory under refrigeration within 2 hours from collection. Parasitized and non-parasitized mussels were placed separately in a single bin containing 120 liters of artificial sea water for 8 hours, in order to stabilize the groups and guarantee standardized initial water conditions. Chemical and physical water conditions in the tank were constantly monitored throughout the experiment in order to avoid any interference with filtration and purification rates of the two examined groups (Marteilia spp. positive or negative). Table 1 reports temperature, $\mathrm{pH}$ and water salinity recorded throughout the experiment. At the end of the acclimatization phase, water in the tank was contaminated by adding a suspension of ATCC 25922 Escherichia coli. A different concentration of $E$. coli was added to the tank at each repetition of the experiment, in order to obtain the following increasing concentrations in water: $36 \mathrm{CFU} / \mathrm{ml}$ in May, $4920 \mathrm{CFU} / \mathrm{ml}$ in June and $6060 \mathrm{CFU} / \mathrm{ml}$ in October. The mussels were exposed to the contamination with $E$. coli for 1 hour and then the contaminated water was discarded and replaced with clean artificial sea water. This was considered the starting point of the purification process. Bivalve molluscs from each group were sampled for microbiological analyses at the following times: before contamination (time $0 \mathrm{BC}$ ), after contamination at the start of the purification process (time $0 \mathrm{PC}$ ), and at $12,24,36,48$ and 70 hours of purification. During purification, each group was also tested for biomarkers at 0 (PC), 24 and 48 hours. Both groups were tested at each sampling time in order to confirm parasite presence/absence in gills and in the digestive tissue.

The enumeration of $E$. coli was carried out in single before contamination and in duplicate after contamination, by using the MPN

\begin{tabular}{|c|c|c|c|}
\hline Month & $\begin{array}{c}\text { Temperature }\left({ }^{\circ} \mathbf{C}\right) \\
\text { range }\end{array}$ & $\mathbf{p H}$ range & Salinity (\%) range \\
\hline May & $17.6-20.3$ & $6.7-7.5$ & $2.5-2.7$ \\
\hline June & $17.7-18.2$ & $6.5-6.7$ & $2.5-2.6$ \\
\hline October & $16.4-16.8$ & $6.5-7$ & $2.5-2.6$ \\
\hline
\end{tabular}

Table 1: Characteristics of water during the three repetitions of the experiment. method according to the ISO 16649. The median between the results of the duplicate samples was considered for statistical evaluations.

The comparison of $E$. coli levels between parasitized and nonparasitized molluscs at each purification time was carried out with the non-parametric Wilcoxon rank-sum statistical method (Stata 11.2 (R) Copyright 1985-2009 StataCorp LP, Statistics/Data Analysis StataCorp 4905 Lakeway Drive College Station, Texas 77845 USA). The presence of Marteilia was evaluated in 10 mussels from each group, using a cytological test according to the following procedure [18]: the valves of each subject were opened and the intravalvular liquid removed. A portion of the digestive gland was collected with tweezers and used to make 4 prints of the digestive gland on a microscope slide. After air-drying it, the slide was fixed in methanol for 2-3 minutes and stained with Hemacolor-2 (red) and 3 (blue) (Merck). The slides were then observed with an optical microscope (BX 51 Olympus) at $1000 \mathrm{X}$ magnifications.

The common target tissue of all biomarkers considered in this work is haemolymph, with the only exception of the neutral lipid accumulation that was evaluated through digestive gland examination. Haemolymph was pooled from 10 mussels per group using a sterile syringe, and then it was placed in $1.7 \mathrm{ml}$ siliconized microcentrifuge tubes. The number of pooled mussels complies with the report of the International Council for the Exploration of the Sea (ICES), where 10 sample animals are considered a sufficient number for the assessment of environmental genotoxic levels and for evaluating the existence of genetic risk zones [19].

Lysosomal membranes stability represents a very sensitive and easily measurable parameter; it can be adopted as an index for nonspecific stress, in relation to the immune system, metabolism and nutrition of organisms [20]. Lysosomes are subcellular organelles surrounded by a semi-permeable membrane which contains numerous hydrolytic enzymes; these are involved in a range of cellular processes, including digestion, defense, and reproduction [21-24]. The Neutral Red Retention (NRR) assay is a useful time-related assay for the investigation of lysosomal stability according to membrane permeability. This assay is based on the incorporation of neutral red (NR) dye in the matrix of cell lysosomes: only lysosomal membranes of healthy cells permanently retain the red dye $[22,25]$. The neutral red retention time (NRRT) was evaluated on freely circulating haemocytes according to the following procedure [26]. Fifty $\mu$ l of haemolymph were dispensed onto a glass microscope slide, placed on ice and left in a dark humid chamber for $15 \mathrm{~min}$. After removing the excess of haemolymph, the slide was covered with $50 \mu$ of NR (Carlo Erba) solution $(10 \mu \mathrm{l}$ of NR in $4.99 \mathrm{ml}$ of artificial sea water). After 15 minutes of incubation on ice in a dark humid chamber, the slide was observed with a light microscope (BX 51 Olympus) at 1000X magnifications. The NRRT was evaluated on three separate slides for each sample; the result was the mean of the results of the three slides, expressed as the number of cells with stable lysosomes out of 50. In order to evaluate differences in health state during the purification process, Mussels with a value of NRRT $>25$ were considered healthy, whilst Mussels with a value of NRRT $<=25$ were considered unhealthy. The difference in NRRT answer between parasitized and parasite-free mussels was performed by using Fisher's exact test.

Haemocytes phagocytic capacity was tested as general biomarker for stress $[27,28]$ in order to determine the efficiency of the immune system for the examined mussels, since any stress causes a deficiency in the mussels immunity, hence provoking a reduction in phagocytosis rate [29]. Haemocytes in mussels represent the first line of defense 
against foreign material, thus their phagocytosis capacity was assessed using Zymosan yeast (Zymosan A - Saccaromyces cerevisiae bioparticles fluorescein - Life Technologies) according to the following procedure: $50 \mu \mathrm{l}$ of the collected haemolymph were allowed to adhere onto a slide for 15 minutes while incubated in a dark room. After adding $50 \mu \mathrm{l}$ commercial working solution of Zymosan yeast, the slide was incubated for 120 minutes in the dark. The activity of haemocytes was assessed through a fluorescence microscope (BX 51 Olympus) by evaluating phagocytic capacity for the first 100 detected cells $[27,28]$. Phagocytosis of the first 100 observed haemocytes was characterized as "active" with more than three ingested Zymosan particles, and "inactive" with one or no ingested Zymosan particles.

Furthermore, the granulocyte/hyalinocyte rate was selected as complementary general biomarker since bivalves exposure to stress conditions could cause an increase in the number of circulating haemocytes, as well as a change in granulocyte/hyalinocyte rate $[21,28,30,31]$ depending on the type of stressing agent. This biomarker was assessed as follows [32]: haemocytes monolayers were prepared onto glass slides and then stained with May-Grünwald-Giemsa (Azur Eosin methylene Blue solution according Giemsa, Panreac); the rate was calculated by recording the number of granulocytes out of 100 haemocytes.

The evaluation of neutral lipid accumulation was assessed on the grounds that these substances represent intra-cellular reserve compounds on which some environmental stress conditions can induce an increase or a consumption [33,34]. This marker was performed on 10 dissected digestive glands taken randomly from each group. The digestive glands were placed on the cryostat chuck, immersed in cold $\left(-70^{\circ} \mathrm{C}\right)$ hexane and then in liquid nitrogen, before being stored at $-80^{\circ} \mathrm{C}$ until analysis. The frozen tissues were cut into $8 \mu \mathrm{m}$ thick sections, placed onto glass slides and then stained. Two slides were prepared for each subject and stained with Oil Red O (Sigma Aldrich) for $15 \mathrm{~min}$. The slides were washed for $1 \mathrm{~min}$ in $60 \%$ isopropyl alcohol, then rinsed in de-ionized water and mounted in glycerol gelatin. The best sections were photographed and digitized. The photographs were analyzed using an open source graphic program and image analysis [35], in order to quantify the presence of neutral lipid accumulations. The result of the images analysis is indicated as the percentage of pixels showing the standardized color for neutral lipids.

\section{Results and Discussion}

It is necessary to point out that the cohabitation of both parasitized and non-parasitized mussels in the same tank does not seem to determine an infection of the latter due to the need of an intermediate host for transmission [36].

During the three repetitions of the experiment, water was always within the physiological requirements for mussels, showing only a slight increase in temperature and $\mathrm{pH}$ during the experiment carried out in May, as shown in Table 1. Microbiological results obtained at different purification times in May, June and October's experiments are shown in Table 2. E. coli contents of all samples are reported as MPN/100 g of flesh and intravalvular liquid (FIL).

Parasitized and non-parasitized molluscs did not show any difference in $E$. coli levels after 12 hours of depuration (Wilcoxon signed rank test: $\mathrm{p}=0.5127, \mathrm{~N}=6$ ), after 24 hours of depuration (Wilcoxon signed rank test: $\mathrm{p}=0.8273, \mathrm{~N}=6$ ), after 36 hours of depuration (Wilcoxon signed rank test: $\mathrm{p}=0.6579, \mathrm{~N}=6$ ), after 48 hours of depuration (Wilcoxon signed rank test: $\mathrm{p}=0.8273, \mathrm{~N}=6$ ) and after 70 hours of depuration (Wilcoxon signed rank test: $\mathrm{p}=0.7963, \mathrm{~N}=6$ ).
The graphical presentation of the trend of $E$. coli during the purification of mussels in the three experiments has been produced using the geometric mean of the analyses, carried out in duplicate for each purification time, as reported in Figures 1-3. For the purpose of statistical analysis, the value of $10 \mathrm{MPN} / 100 \mathrm{~g}$ was assigned to the samples showing a value of $<18 \mathrm{MPN} / 100 \mathrm{~g}$, corresponding to the minimum limit of quantification.

The results show a moderate contamination rate in 2 experiments out of 3 and only the repetition of June showed a high MPN value for E. coli. Figure 1 shows that despite the high level of contamination in June, mussels' purification rate is comparable with May and October's experiments. The maximum purification rate was always reached in

\begin{tabular}{|c|c|c|c|c|c|}
\hline \multirow[t]{2}{*}{ Month } & \multirow[t]{2}{*}{$\begin{array}{c}\text { Purification time } \\
\text { (hours) }\end{array}$} & \multirow{2}{*}{\multicolumn{2}{|c|}{$\begin{array}{l}\text { Mussels parasitized with } \\
\text { Marteilia spp. }\end{array}$}} & \multirow{2}{*}{\multicolumn{2}{|c|}{$\begin{array}{c}\text { Marteilia-free } \\
\text { mussels }\end{array}$}} \\
\hline & & & & & \\
\hline \multirow{7}{*}{ May } & $0(B C)$ & \multicolumn{2}{|c|}{340} & \multicolumn{2}{|c|}{40} \\
\hline & $0(\mathrm{PC})$ & 490 & 700 & 310 & 330 \\
\hline & 12 & 140 & 330 & 40 & 110 \\
\hline & 24 & 40 & 130 & 20 & 20 \\
\hline & 36 & 50 & 80 & $<18$ & 20 \\
\hline & 48 & $<18$ & 50 & $<18$ & 70 \\
\hline & 70 & $<18$ & $<18$ & $<18$ & $<18$ \\
\hline & $0(\mathrm{BC})$ & \multicolumn{2}{|c|}{$<18$} & \multicolumn{2}{|c|}{$<18$} \\
\hline \multirow[t]{7}{*}{ June } & $0(\mathrm{PC})$ & 9200 & 16000 & 9200 & 16000 \\
\hline & 12 & 5400 & 9200 & 1700 & 16000 \\
\hline & 24 & 340 & 1700 & 220 & 490 \\
\hline & 36 & 330 & 490 & 270 & 330 \\
\hline & 48 & 130 & 170 & 80 & 130 \\
\hline & 70 & 110 & 140 & 110 & 170 \\
\hline & $0(\mathrm{BC})$ & \multicolumn{2}{|c|}{$<18$} & \multicolumn{2}{|c|}{$<18$} \\
\hline \multirow[t]{6}{*}{ October } & $0(\mathrm{PC})$ & 330 & 490 & 170 & 460 \\
\hline & 12 & 230 & 790 & 20 & 110 \\
\hline & 24 & $<18$ & $<18$ & 20 & 50 \\
\hline & 36 & $<18$ & $<18$ & $<18$ & $<18$ \\
\hline & 48 & 20 & 50 & 20 & 20 \\
\hline & 70 & $<18$ & $<18$ & $<18$ & $<18$ \\
\hline
\end{tabular}

$\mathrm{BC}=$ before contamination; $\mathrm{PC}=$ post contamination

Table 2: Results of microbiological analyses (E. coli) performed on parasitized and parasite-free mussels (M. galloprovincialis) at different purification times.

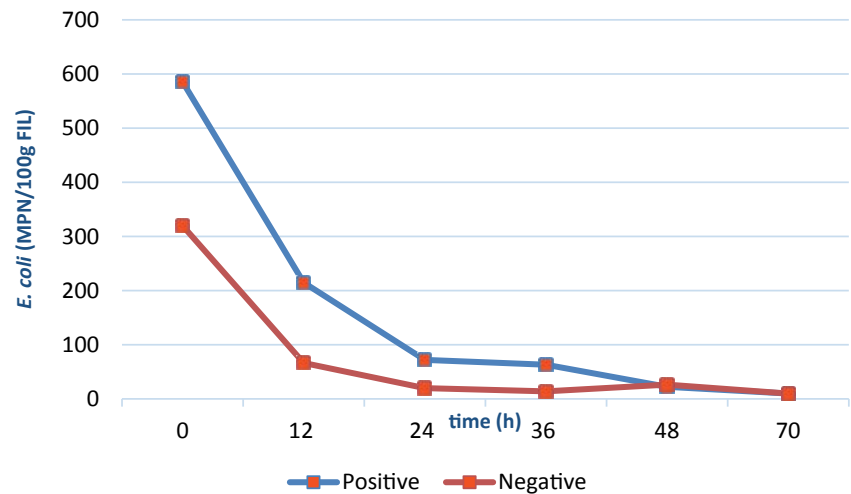

Figure 1: Trend of $E$. coli concentration in two groups of mussels ( $M$. galloprovincialis) during purification in the experiment carried out in May. Positive mussels are parasitized with Marteilia, negative mussels are Marteilia-free. 


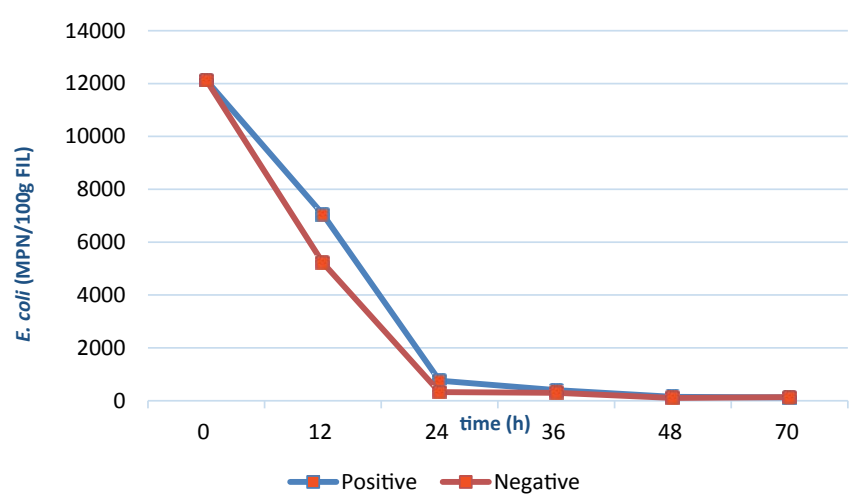

Figure 2: Trend of $E$. coli concentration in two groups of mussels $(M$. galloprovincialis) during purification in the experiment carried out in June. Positive mussels are parasitized with Marteilia, negative mussels are Marteilia-free.

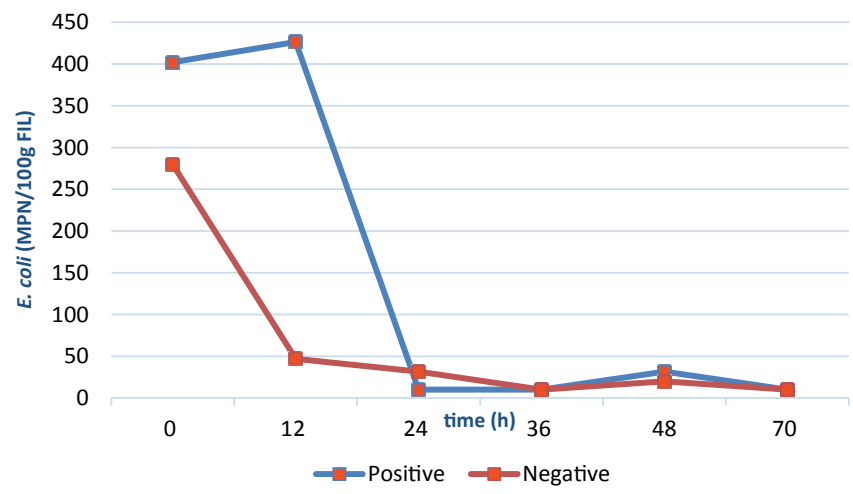

Figure 3: Trend of $E$. coli concentration in two groups of mussels $(M$. galloprovincialis) during purification in the experiment carried out in October. Positive mussels are parasitized with Marteilia, negative mussels are Marteilia-free.

the first 24 hours. In October's experiment repetition, unlike in May's and June's, purification rate is higher on parasite-free mussels than in mussels parasitized with Marteilia spp. However, at 48 hours all batches had similar levels of residual E. coli contamination.

The NRR results are reported in Table 3 and show a basal level of cells with stable lysosomes at greater frequency in summer (June) and autumn (October) than in spring (May). The NRR assay also highlights differences between parasitized and parasite-free groups, where the latter shows greater levels of stable cells. There is a difference in NRR answer between parasitized and parasite-free mussels (Fisher's exact: $\mathrm{p}=0.05$ ). On the other hand, different situations can be observed throughout the purification process, showing an increased frequency of stable cells for some groups and a decreased one for others. These changes do not seem related to parasites presence nor to purification time.

Results of the phagocytosis rate are reported in Table 4 and are expressed as the percentage of active cells out of 100 observed haemocytes. Except for the mussels at 24 hours in October's experiment, results do not show big differences related to season or purification time.

As previously reported, the granulocyte/hyalinocyte rate test verifies how total haemocyte number and relative percentage of haemocyte types change in relation to the mussels different health states. The relative percentage of haemocyte types recorded is reported in Table 5. Physiologically speaking, granulocytes represent $80 \%$ of the haemocyte population with a lower number of hyalinocytes [37]. Changes in this rate may represent an alteration in mussels' defense mechanism. The results show a moderate difference between the two groups, with lower percentages of granulocytes in parasitized mussels. At the same time, purification time does not seem to affect the granulocyte rates, except for a slight decrease observed during June's experiment repetition [38,39].

\begin{tabular}{|c|c|c|c|}
\hline Month & $\begin{array}{c}\text { Purification time } \\
\text { (hours) }\end{array}$ & \multicolumn{2}{|l|}{} \\
\hline & & $\begin{array}{c}\text { Mussels parasitized } \\
\text { with Marteilia spp. }\end{array}$ & $\begin{array}{c}\text { Marteilia-free } \\
\text { mussels }\end{array}$ \\
\hline & 0 & 21 & 30 \\
\hline May & 24 & 28 & 38 \\
\hline & 48 & 26 & 40 \\
\hline & 0 & 17 & 47 \\
\hline June & 24 & 30 & 30 \\
\hline & 48 & 24 & 23 \\
\hline October & 0 & 21 & 38 \\
\hline & 24 & 21 & 29 \\
\hline
\end{tabular}

"expressed as number of stable cells out of 50

Table 3: Results of the Neutral Red Retention Test performed on parasitized and parasite-free mussels ( $M$. galloprovincialis) at different purification times.

\begin{tabular}{|c|c|c|c|}
\hline \multirow{2}{*}{ Month } & $\begin{array}{c}\text { Purification } \\
\text { time (hours) }\end{array}$ & \multicolumn{2}{|c|}{} \\
\hline \multirow{4}{*}{ May } & & $\begin{array}{c}\text { Mussels parasitized with } \\
\text { Marteilia spp. }\end{array}$ & $\begin{array}{c}\text { Marteilia-free } \\
\text { mussels }\end{array}$ \\
\cline { 2 - 4 } & 0 & 78 & 85 \\
\cline { 2 - 4 } & 24 & 89 & 85 \\
\hline \multirow{3}{*}{ June } & 48 & 91 & 84 \\
\cline { 2 - 4 } & 0 & 66 & 78 \\
\hline \multirow{3}{*}{ October } & 24 & 78 & 58 \\
\cline { 2 - 4 } & 48 & 73 & 65 \\
\cline { 2 - 4 } & 24 & 81 & 76 \\
\hline
\end{tabular}

Table 4: Number of haemocytes out of 100 able to phagocytize three or more zymosan yeast observed in parasitized and parasite-free mussels ( $M$. galloprovincialis) at different purification times.

\begin{tabular}{|c|c|c|c|}
\hline Month & $\begin{array}{c}\text { Purification time } \\
\text { (hours) }\end{array}$ & \multicolumn{2}{|c|}{} \\
\hline & & $\begin{array}{c}\text { Mussels parasitized with } \\
\text { Marteilia spp. }\end{array}$ & $\begin{array}{c}\text { Marteilia-free } \\
\text { mussels }\end{array}$ \\
\hline & 0 & 63 & 71 \\
\hline May & 24 & 77 & 74 \\
\hline & 48 & 69 & 83 \\
\hline & 0 & 68 & 87 \\
\hline June & 24 & 69 & 73 \\
\hline & 48 & 49 & 57 \\
\hline October & 0 & 82 & 74 \\
\hline & 24 & 68 & 65 \\
\hline
\end{tabular}

Table 5: Granulocyte/hyalinocyte rate reported as the number of granulocytes counted out of 100 haemocytes, observed in parasitized and parasite-free mussels (M. galloprovincialis) at different purification times. 


\begin{tabular}{|c|c|c|c|}
\hline Month & $\begin{array}{c}\text { Purification time } \\
\text { (hours) }\end{array}$ & \multicolumn{2}{|c|}{} \\
\hline & & $\begin{array}{c}\text { Mussels parasitized with } \\
\text { Marteilia spp. }\end{array}$ & $\begin{array}{c}\text { Marteilia-free } \\
\text { mussels }\end{array}$ \\
\hline \multirow{3}{*}{ May } & 0 & 12.48 & 16.64 \\
\cline { 2 - 4 } & 24 & 14.08 & 10.82 \\
\hline \multirow{3}{*}{ June } & 48 & 10.64 & 9.70 \\
\hline & 0 & 8.37 & 8.89 \\
\hline \multirow{3}{*}{ October } & 24 & 11.23 & 11.6 \\
\hline & 48 & 11.06 & 11.82 \\
\hline & 0 & 14.57 & 15.03 \\
\hline & 24 & 15.94 & 8.64 \\
\hline
\end{tabular}

Table 6: Percentages of neutral lipids detected in an area of 1447680 pixels observed in parasitized and parasite-free mussels ( $M$. galloprovincialis) at different purification times.

Results of the evaluation of neutral lipid accumulation are reported in Table 6. The percentage shows some slight differences between groups, even if a clear tendency to decrease or increase through season, groups and purification time cannot be observed. However, it is well known that the accumulation of neutral lipids can be influenced by environmental stress in different ways [33,34]. In general, xenobiotic substances, especially organic contaminants, can promote accumulation of neutral lipids, although particular environmental conditions can induce the cell to consume these reserves.

\section{Conclusion}

The present study shows that the presence of Marteilia spp. does not affect purification rate of $M$. galloprovincialis. Considering the biomarkers response, no stress conditions were detected during the experiment, although difference between parasitized and nonparasitized mussels was evident on one of the selected biomarkers. Therefore, even if there is a possibility that parasites can create stress in parasitized mussels, there is no evidence that this may lead to a change in purification rate.

The results suggest that the purification process can be performed even when bivalve molluscs have some parasites; it also demonstrates that, in the Adriatic Sea conditions, the presence of Marteilia in mussels should be investigated in order to define how this could affect the real production.

\section{Acknowledgements}

This research was funded by Italian Ministry of Health

\section{References}

1. Denis L, Alliot E, Grzebyk D (1999) Clearance rate responses of Mediterranean mussels, Mytilus galloprovincialis, to variations in the flow, water temperature, food quality and quantity. Aquatic Living Resources 12: 279-288.

2. Renwrantz $L$ (1990) Internal defence system of Mytilus edulis. In: Studies in Neuroscience of Mytilus edulis Manchester Univeristy press 256-275.

3. Kim Y, Powell EN, Wade TL, Presley BJ (2008) Relationship of parasites and pathologies to contaminant body burden in sentinel bivalves: NOAA Status and Trends 'Mussel Watch' Program. Mar Environ Res 65: 101-127.

4. Lees D (2000) Viruses and bivalve shellfish. Int J Food Microbiol 59: 81-116.

5. Office International Des Epizooties (2006) Diseases of crustaceans. In: Manual of Diagnostic Tests for Aquatic Animals 5th edition 93-243.

6. Pipe RK, Coles JA, Thomas ME, Fossato VU, Pulsford AL (1995) Evidence for environmentally derived immunomodulation in mussels from the Venice lagoon. Aquatic Toxicology 32: 59-73.

7. Carrasco N, Green T, Itoh N (2016) Marteilia spp. parasites in bivalves: a revision of recent studies. Journal of Invertebrate Pathology 131: 43-57.
8. Ching EWK, Siu WHL, Lam PKS, Xu L, Zhang Y, et al. (2001) DNA adduct formation and DNA strand breaks in green lipped mussels (Perna viridis) exposed to benzo(a)pyrene: dose and time dependent relationship. Mar Pollut Bull 42: 603-610.

9. Kessiba A, Hoarau P, Barelli MG, Aissa P, Romeo M (2001) Biochemical response of the mussel Mytilus galloprovincialis from Bizerta (Tunisia) to chemical pollutant exposure. Arch Environ Contam Toxicol 40: 222-229.

10. Love DC, Lovelace GL, Sobsey MD (2010) Removal of Escherichia coli, Enterococcus fecalis, coliphage MS2, poliovirus, and hepatitis A virus from oysters (Crassostrea virginica) and hard shell clams (Mercinaria mercinaria) by depuration. International Journal of Food Microbiology 143: 211-217.

11. Fairley CA (1988) A Computerized Coding system for organs, tissues, Lesions, and parasites of bivalve Mollusks and its application in pollution monitoring with Mytilus edulis. Marine Environmental Research 24: 243-249.

12. Brenner M, Broeg K, Frickenhaus S, Buck BH, Koehler A (2014) Multi-biomarker approach using the blue mussel (Mytilus edulis L.) to assess the quality of marine environments: Season and habitat-related impacts. Mar Environ Res 95: 13-27.

13. Berthe FCJ, Le Roux F, Adlard RD, Figuera A (2004) Marteiliosis in molluscs: A review. Aquat Living Resour. 17: 433-448.

14. Harding JM, Couturiera C, Parsons GJ, Ross NW (2004) Evaluation of the neutral red assay as a stress response indicator in cultivated mussels (Mytilus spp.) in relation to post-harvest processing activities and storage conditions. Aquaculture 231: 315-326.

15. Mosca F, Gioia L, Narcisi V, Marozzi S, Tiscar PG (2005) Comparative study by flow cytometry, confocal microscopy and fluorimetry in micromethod phagocytosis in hemocytes of Mytilus galloprovincialis. Ichthyopathology 2 : 145-154.

16. Rayyan A, Damianidis P, Antoniadou C, Chintiroglou CC (2006) Protozoan parasites in cultured mussels Mytilusgalloprovincialisin the Thermaikos Gulf (north Aegean Sea, Greece). Dis Acquat organ 70: 251-254.

17. Schneider CA, Rasband WS, Eliceiri KW (2012) NIH Image to ImageJ: 25 years of image analysis. Nat Methods 9: 671-675.

18. Mosca F, Narcisi V, Calzetta A, Gioia L, Finoia MG, et al. (2013) Effects of high temperature and exposure to air on mussel (Mytilus galloprovincialis, Lmk 1819) hemocyte phagocytosis: Modulation of spreading and oxidative response. Tissue Cell 45: 198-203.

19. Davies IM, Vethaak AD (2012) Integrated marine environmental monitoring of chemicals and their effects. ICES Cooperative Research Report No. 315.

20. Luengen AC, Friedman CS, Flegal AR (2000) Immune response of two species of mussels (Mytilus californicus and Mytilus galloprovincialis/trossulus hybrid) to pollutants in San Francisco Bay. Journal of Shellfish Research 19: 599.

21. Ferreira A, Dolder H (2003) Cytochemical study of spermiogenesis and mature spermatozoa in the lizard Tropidurus itambere (Reptilia, Squamata). Acta Histochem 105: 339-352.

22. Mayrand E, St-Jean SD, Courtenay SC (2005) Haemocyte responses of blue mussels (Mytilus edulis L.) transferred from a contaminated site to a reference site: can the immune system recuperate? Aquaculture Research 36: 962-971.

23. Oubella $R$ (1997) Immunomodulation in populations of bivalve molluscs of the Brest. Annals of the Institute Océanographiqu 73: 77-87.

24. Signa G, Di Leonardo R, Vaccaro A, Tramati CD, Mazzola A, et al. (2015) Lipid and fatty acid biomarkers as proxies for environmental contamination in caged mussels Mytilus galloprovincialis. Ecological Indicators 57: 384-394.

25. Moore MN (1976) Cytochemical demonstration of latency of lysosomal hydrolases in the digestive cells of the common mussel, Mytilus edulis, and changes induced by thermal stress. Cell Tissue Res 175: 279-287.

26. Riisgård HU, Kittner C, Seerup DF (2003) Regulation of opening state and filtration rate in filter-feeding bivalves (Cardium edule, Mytilus edulis, Mya arenaria) in response to low algal concentration. Journal of Experimental Marine Biology and Ecology 284: 105-127.

27. Luengen AC, Friedman CS, Raimondi PT, Flegal AR (2004) Evaluation of mussel immune responses as indicators of contamination in San Francisco Bay. Mar Environ Res 57: 197-212.

28. Moore MN, Allen IJ, Mc Veigh A (2006) Environmental prognostics: an 
integrated model supporting lysosomal stress responses as predictive biomarkers of animal health status. Mar Environ Res 61: 278-304.

29. Oliveira J, Cunha A, Castilho F, Romalde JL, Pereira MJ (2011) Microbia contamination and purification of bivalve shellfish: Crucial aspects in monitoring and future perspectives - A mini-review. Food Control 22: 805-816.

30. Oliver LM, Fisher WS, Winstead JT, Hemmer BL, Long ER (2001) Relationships between tissue contaminants and defense-related characteristics of oysters (Crassostrea virginica) from five Florida bays. Aquat Toxicol 55: 203-222.

31. Pipe RK (1992) Generation of reactive oxygen metabolites by the haemocytes of the mussel Mytilus edulis. Dev Comp Immunol 16: 111-122.

32. Carballal MJ, Lopez MC, Azevedo C, Villalba A (1997) Hemolymph cell types of the mussel Mytilus galloprovincialis. Dis Aquat org 29: 127-135.

33. Da Ros L, Moschino V, Guerzoni S, Haldorsson H (2007) Lysosomal responses and metallothionein induction in the blue mussel Mytilus edulis from the southcoast of Iceland. Environment International 33: 362-369.

34. Moore MN, Lowe D, Köhler A (2004) Biological effects of contaminants: Measurement of lysosomal membrane stability. ICES Techniques in Marine Environmental Sciences 36
35. Ringwood AH, Conners DE, Hoguet J, Rinwood LA (2005) Lysosomal destabilization assays for estuarine organisms. In: Ostrander GK (ed.) Techniques in aquatic toxicology, CRC Press, Boca Raton, FL, USA 2.

36. Berthe FCJ, Pernas M, Zerabib M, Haffner P, Thebault A, et al. (1998) Experimental transmission of Marteilia refringens with special consideration of its life cycle. Dis Aquat Org 34: 135-144.

37. Donaghy L, Volety AK (2011) Functional and metabolic characterization of hemocytes of the green mussel, Perna viridis: in vitro impacts of temperature. Fish Shellfish Immunol 31: 808-814.

38. Fisher WS, Oliver LM, Winstead JT, Long ER (2000) A survey of oysters Crassostrea virginica from Tampa Bay, Florida: associations of interna defense measurements with contaminant burdens. Aquat Toxicol 51: 115-138.

39. Viarengo A, Lowe D, Bolognesi C, Fabbri E, Koehler A (2007) The use of biomarkers in biomonitoring: a 2-tier approach assessing the level of pollutantinduced stress syndrome in sentinel organisms. Comp Biochem Physiol C Toxicol Pharmacol 146: 281-300.
Citation: Canonico C, Barchiesi F, Rea S, Felici A, Loschi A, et al. (2016) Depuration Capacity of Mussels (Mytilus galloprovincialis) in Presence of Marteilia Spp. Parasites. J Marine Sci Res Dev 6: 187. doi:10.4172/21559910.1000187
OMICS International: Publication Benefits \& Features

Unique features:

- Increased global visibility of articles through worldwide distribution and indexing

Showcasing recent research output in a timely and updated manner

Special issues on the current trends of scientific research

Special features:

- $700+$ Open Access Journals

$50,000+$ Editorial team

Rapid review process

Quality and quick editorial, review and publication processing

- Indexing at major indexing services

Sharing Option: Social Networking Enabled

- Authors, Reviewers and Editors rewarded with online Scientific Credits

- Better discount for your subsequent articles

Submit your manuscript at: http://www.omicsonline.org/submission 